\title{
Contents, Vol. 16, 1973
}

Vol. 16,1973

Human Development

\section{Editors:}

Advisory Editors:

M.J. Langeveld, Bilthoven

K.F. Riegel, Ann Arbor,

Mich.

H. Thomae, Bonn

J. E. Birren, Los Angeles,

Calif.

U. Bronfenbrenner, Ithaca, N.Y.

Ch. Buhler, Los Angeles,

Calif.

M. Cesa-Bianchi, Milan

J. de Wit, Amsterdam

J. Gewirtz, Bethesda, Md.

E.J. Gibson, Ithaca, N.Y.

W. W. Hartrup,

Minneapolis, Minn.

H. Heckhausen, Bochum

C.B. Hindley, London

T. Husen, Stockholm

J. Koch, Praha

L. Koklberg, Cambridge,

Mass.

U. Lehr, Bonn

J. Linhart, Praha

D. McNeill, Chicago, 111.

R. Meili, Bern

F. Monks, Nijmegen

P.H. Mussen, Berkeley,

Calif.

B. Neugarten, Chicago, 111.

H.W. Reese, Morgantown,

W.Va.

R. Rosenmayer, Wien

I.E. Sigel, Buffalo, N.Y.

A. Skard, Oslo 
L.W. Sontag, Yellow

Springs, O.

I. Tolicic, Ljubljana

M.W. Weir, Urbana, 111.

A.T. Welford, Adelaide

J. F. Wohlwill, University

Park, Pa.

R. Zazzo, Paris

S. Karger · Basel · München · Paris · London · New York · Sydney Arnold-Böcklin-Strasse 25, CH-4011 Basel (Switzerland)

All rights, including that of translation into other languages, reserved.

Photomechanic reproduction (photocopy, microcopy) of this volume or parts thereof without special permission of the publishers is prohibited.

(C) Copyright 1973 by S.Karger AG, Verlag für Medizin und Naturwissenschaften, Basel Printed in Switzerland by Buchdruckerei Gasser \& Cie. AG, Basel

Contents

No. 1-2

Riegel, K.F. (Ann Arbor, Mich.): An Epitaph for a Paradigm. Intriduction for a

Symposium 1

Fischer, Constance T. (Pittsburgh, Pa.): Intelligence contra IQ. A Human Science

Critique and Alternative to the Natural Science Approach to Man . . 8

Looft, W. R. (University Park, Pa.): Conceptions of Human Nature, Educational

Practice, and Individual Development

21

Tulkin, S.R. and Konner, M.J. (Buffalo, N.Y.): Alternative Conceptions of

Intellectual Functioning $\quad 33$

Weiner, B. (Los Angeles, Calif.): From Each According to His Abilities: The Role

of Effort in a Moral Society 53

Furth, H. G. (Washington, D.C.): Piaget, IQ and the Nature-Nurture Controversy 61

Overton, W.F. (Philadelphia, Pa.): On the Assumptive Base of the Nature-Nurture Controversy:

Additive versus Interactive Conceptions .... 74

Wohlwill, J.F. (University Park, Pa.): The Concept of Experience: S or R? .. 90

Lewis, M. (Princeton, N.J.): Infant Intelligence Tests: Their Use and Misuse . 108

Elias, M.F. (Morgantown, W. Va.): Disciplinary Barriers to Progress in Behavior

Genetics: Defensive Reactions to Bits and Pieces 119

No. 3

Krantz, D.L. and Wiggins, Lynda (Lake Forest, 111.): Personal and Impersonal

Channels of Recruitment in the Growth of Theory 133

Kuhn, Deanna (New York, N.Y.): Imitation Theory and Research from a

Cognitive Perspective 157

Kuypers, J.A. and Bengtson, V.L. (Berkeley, Calif.): Social Breakdown and

Competence. A Model of Normal Aging 181

Feitelson, Dina and Ross, Gail S. (Jerusalem): The Neglected Factor-Play . . 202

Ziv, A. and Luz, M. (Tel-Aviv): Manifest Anxiety in Children of Different Socioeconomic Levels 
Hoyer, W. J.; Labouvie, Gisela V., and Baltes, P.B. (Syracuse, N.Y.): Modifica tion of Response Speed Deficits and Intellectual Performance in the

Elderly 233

Developmental Issue

Meacham, John A. and Spielman, Karen S. (Ann Arbor, Mich.): Dialectics and Development: Soviet Preschool Psychology. A review of A.V. Zaporoz-

hets andD.B. Elkonin (ed.) 243

Varia 248

Contents IV

No. 4

Tucker, Don M. (University Park, Pa.): Some Relationships between Individual and Group Development 249

Buss, Allan R. (Edmonton): A Conceptual Framework for Learning Effecting the Development of Ability Factors 273

Braun, P.H. (Willowdale): Finding Optimal Age Groups for Investigating AgeRelated Variables 293

Freeberg, N.E. and Rock, D.A. (Princeton, N.J.): Dimensional Continuity of Interests and Activities during Adolescence 304

Developmental Issues

Harris, Adrienne (Toronto): Structure, Transformation, Interaction: Develop mental and Historical Aspects. A Report on an Interdisciplinary

Conference 317

No. 5

Bonvillian, John D.; Charrow, Veda R., and Nelson, Keith E. (Stanford, Calif.): Psycholinguistic and Educational Implications of Deafness . . 321

Riegel, Klaus F. (Ann Arbor, Mich.): Dialectic Operations: The Final Period of Cognitive Development 346

Gutkin, Daniel C. (East Lansing, Mich.): An Analysis of the Concept of Moral Intentionality 371

Anooshian, Linda and Carlson, Jerry S. (Riverside, Calif.): A Study of Mental Imagery and Conservation within the Piagetian Framework 382

Bergman, Lars R. (Stockholm): Bloom's Developmental Formula A Methodolo gical Note 395

No. 6

Reese, H.W. (Morgantown, W.Va.): Models of Memory and Models of Develop ment 397

Bronckart, J.-P. (Geneve): The Regulating Role of Speech. A Cognitivist Approach 417

Hall, W.S. and Freedle, R.O. (Princeton, N.J.): A Developmental Investigation of Standard and Nonstandard English among Black and White Children 440 